\title{
Energy Audit for Complex Energy System Simulated Using TRNSYS Software
}

\author{
Volodymyr Bezhan $^{a}$, Volodymyr Zhytarenko ${ }^{a}$, Olga Yakovleva $^{b}$, \\ Oleksii Ostapenko ${ }^{b}$, Mykhailo Khmelniuk ${ }^{b, *}$ \\ ${ }^{a}$ Pryazovskyi State Technical University Mariupol, Universitetska St. 7, Mariupol, 87555, Ukraine \\ ${ }^{b}$ Odessa National Academy of Food Technologies, Dvoryanska St. 1/3, Odessa, 65083, Ukraine
}

Received: November 21, 2019. Revised: February 05, 2020. Accepted: February 12, 2020.

(C) 2020 The Authors. Published by Lviv Polytechnic National University.

\begin{abstract}
Energy audit provides a way to derive energy potential and to develop energy saving program in order to improve energy efficiency during early stage design decision process for new-developed systems that can reduce costs for project owner and for customer. This paper presents utilization of complex energy system (solar assisted heat pump) for heating and cooling purposes. Simulation has been carried out using TRNSYS 18 software for a complex energy system located in northern latitude. The results of such system configurations are presented in the paper. The results show that the solar collector, set at the angle of 30 degrees, facing southwest, with azimuth of $45^{\circ}$, offers up to $95 \%$ of optimal solar energy. For east or west orientation, it is possible to obtain up to $85 \%$ energy, with roof angles of $25^{\circ}$ to $40^{\circ}$. By applying the solar thermal collector the customer can reduce borehole depletion that can provide great opportunities for construction sector.
\end{abstract}

Keywords: energy audit; TRNSYS 18; ground source heat pump; air-conditioning; energy efficiency.

\section{Introduction}

Buildings and structures together with construction sector consume over $1 / 3^{\text {rd }}$ of the global power consumption (36\%) [1]. These sectors account for nearly $40 \%$ of the total $\mathrm{CO}_{2}$ emissions and this parameter is steadily increasing driven by an increase in power demand due to simple way to access energy for developing countries, more intensive utilization of power-consuming devices as well as rapid growth of building floor area $(\cong 3 \%)$ annually on the global arena [2]. At the same time, heating has over $1 / 4^{\text {th }}$ of power saving potential, water heating over $20 \%$, cooling over $1 / 4^{\text {th }}$ of the building power saving potential if we look at the developing countries' economies and $12 \%$ of global power saving potential. Since the 1970's oil crisis, voluntary and mandatory certification programs such as Building Research Establishment's Environmental Assessment Method (BREEAM), LEED as well as Energy Performance of Buildings Directive (EPBD) were developed and introduced at different levels from regional to international. These Programs are intended for energy consumption reduction alongside with the construction sector environmental impact decrease [3]-[6].

For operational stage of buildings, power can be used for the following purposes: lighting, hot water preparation, heating, ventilation and air-conditioning (HVAC) systems operation. An approach designed to reduce the operational energy of buildings is, in almost all cases, the main focus of energy conservation measures for buildings [7]. It happens due to the fact that at the operational stage of construction the amount of consumed power is higher than the total amount of power consumed during other life-cycle stages [8], [9].

As a result, buildings power utilization and their environmental impact decrease remained a matter of deep concern. In this regard, there is a need to define the best measures to achieve these goals. The importance of

\footnotetext{
* Corresponding author. Email address: hmel_m@ukr.net
}

This paper should be cited as: V. Bezhan, V. Zhytarenko, O. Yakovleva, O. Ostapenko, M. Khmelniuk. Energy audit for complex energy system simulated using TRNSYS software. Energy Engineering and Control Systems, 2020 , Vol. 6, No. 1, pp. 33 - 42. https://doi.org/10.23939/jeecs2020.01.033 
decarbonization or power utilization reduction in the buildings is growing up and the European Union had published the energy performance by buildings [10].

It is strongly encouraged to develop approaches to improve energy efficiency by reducing energy consumption in buildings and to mainly use renewable energy including renewable energy generated on-site, geothermal energy (source soil).The building is located in Odessa, Ukraine, in a region with hot climate. The goal is to reduce the building energy needs both for heating and cooling.

The growing interest in energy efficiency improvement and in renewable energy use has put the geothermal heat pumps in the spotlight. Also known as "ground-source" heat pumps (GSHP), this type of energy system can provide a house with heat, air-conditioning (cooling) and hot water if it is required. GSHP can meet customer requirements efficiently with less cost than most other HVAC options. Energy efficiency is the primary advantage of a GSHP. The Environmental Protection Agency evaluates that a GSHP can reduce energy consumption up to $44 \%$ compared to air-source heat pumps. And customer interested in GSHP can reduce up to $72 \%$ compared to an HVAC system that integrates electric resistance heat with common central air-conditioning. GSHP can reduce electricity use for heating propose by nearly $50 \%$ compared to electric resistance heating such as furnaces and baseboard heaters. Efficient heat pumps also dehumidify better than standard central air conditioners, resulting in less energy usage and more cooling comfort during summer period.

\section{Ground-source heat pump system description}

The refrigerant R410A was selected as a working substance. When considering the coefficient of performance for the compressor, R410A does not seem to be the best solution. As soon as we extend the scope of the analysis and consider the complete energy system immediate advantages are highlighted. Focusing first on the condenser, where the hot water is produced, we can see that due to the fact that R410A has no glide the dew condensing temperature is lower than with $\mathrm{R} 407 \mathrm{C}$ by an average of $2 \mathrm{~K}$, leading to higher system efficiency. The sub-cooling effect plays an important role. R410A with zero glide is able to maintain a constant sub-cooling of $3.5 \mathrm{~K}$ without a liquid receiver. R407C systems need a liquid receiver to keep a stable sub-cooling of $1.5 \mathrm{~K}$. In the air coil the same evaporating temperature is used for R410A and R407C. One additional effect of the absence of the glide is that the unit will need less defrost cycles but this effect has not been taken into account in this paper because it strongly depends on the fin and air flow design.

Approximately $1 / 3$ of the total energy consumption comes from heating buildings in Ukraine. Energy-saving building technologies, as well as the cost of the heating system can significantly reduce energy consumption, thereby helping to save natural resources and protect the earth's atmosphere. Considerable savings potential lies in the system of hot water. Thus, the solar collectors in combination with the ground-source heat pump in our latitudes, it is in the summer months represent the most interesting alternative to the use of the conventional heating systems. The following system was proposed for a house with the floor area of approximately $200 \mathrm{~m}^{2}$. The house has two heating systems: conventional natural gas heater and a ground-source heat pump. The study period was considered 170 days (average heating period). A schematic diagram of the ground source heat pump system is given in Fig.1. In the current work, a heat exchanger has been added between the suction line and liquid line.

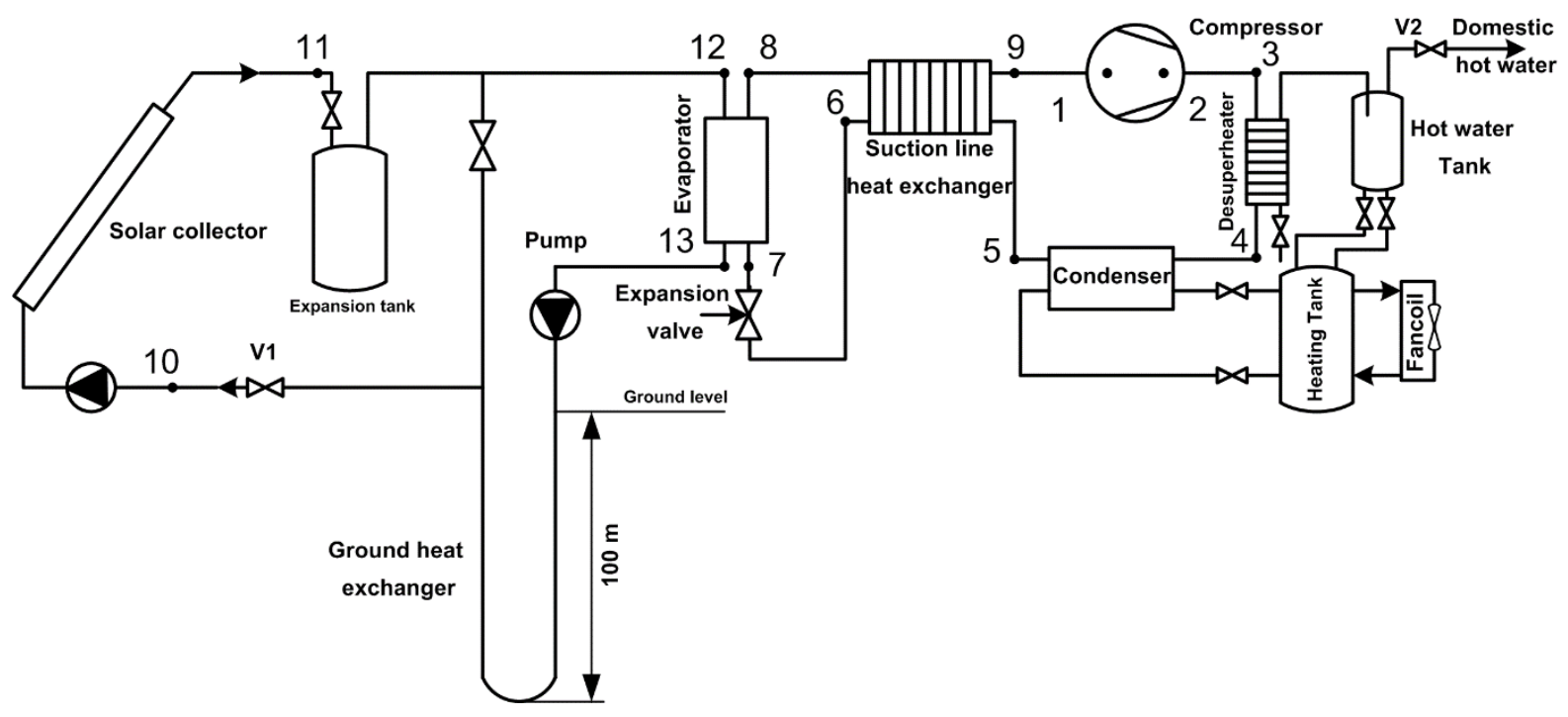

Fig.1. Schematic diagram of the energy system components. 
Energy and mass flows balances are provided for the system and all its components. A general mass balance can be expressed in rate form as:

$$
\sum \dot{m}_{\text {in }}=\sum \dot{m}_{\text {out }}
$$

where $\dot{m}$ is the mass flow rate; subscript in stands for inlet and out for outlet.

Energy balances, equating total energy inputs $\left(\dot{E}_{\text {in }}\right)$ to total energy outputs $\left(\dot{E}_{\text {out }}\right)$, can be written as follows:

$$
\sum \dot{E}_{\text {in }}=\sum \dot{E}_{\text {out }}
$$

\subsection{Heat pump modelling and analysis}

The main task of the study is a comparative analysis of heating systems using solar collectors, comparing operating modes:

1) Heat pump;

2) Heat pump with parallel inclusion of solar system;

3) Heat pump with a consistent inclusion of solar system.

The first mode is only a heat pump without the use of additional equipment. The second mode is characterized by the inclusion of solar collectors to produce additional heat for heating and hot water supply. The third mode is the inclusion of solar collectors in series between the geothermal circuit and the heat pump, to increase the temperature of the coolant and additional soil regeneration.

The performance of a solar system depends more on its ability to compensate for losses between the heat carrier and the environment. When the solar collectors are switched on in parallel, the temperature of the coolant at the inlet to the collectors is determined by the temperature in the buffer tank. At the same time, with successive switching on, the temperature is determined by the temperature of the coolant at the outlet of the geothermal heat exchanger. As this temperature is lower than the buffer capacity of the solar collector, one can expect an increase in the performance of the geothermal circuit.

For analysis purposes, the following assumptions were made:

1) the storage tank temperature, which is connected to storage tank mass, collector type and area, is calculated for hourly input from 08:00 to 18:00;

2) all processes are steady-state and steady-flow with negligible potential and kinetic energy effects and no chemical or nuclear reactions;

3) heat transfer to the system and work transfer from the system are positive;

4) in this study, the reference state is taken to be the state of environment at which the temperature and the atmospheric pressure on $15 \mathrm{July} 2018$ were $30^{\circ} \mathrm{C}$ and $101.3 \mathrm{kPa}$, respectively. The thermodynamic properties of water, air and R410A are found using the REFPROP software package.

The conventional parameter that has been used to describe the heat pump performance is COP (coefficient of performance, $\left.C O P_{G S H P}\right)$, which is the ratio of the quality of the useful heat output $\left(\dot{Q}_{c}\right)$ to the quantity of work accomplished by the compressor $\left(\dot{w}_{\text {comp }}\right)$ :

$$
\operatorname{COP}_{G S H P}=\frac{\dot{Q}_{c}}{\dot{W}_{\text {comp }}}
$$

in terms of the electrical energy at the input

$$
C O P_{G S H P}=\frac{\dot{Q}_{c}}{\dot{W}_{c o m p, e}}
$$

for the whole system

$$
C O P_{\text {sys }}=\frac{\dot{Q}_{c}}{\dot{W}_{\text {comp }}+\dot{W}_{\text {pumps }}+\dot{W}_{\text {fans }}}
$$


for the whole system in terms of the electrical energy at the input

$$
C O P_{s y s}=\frac{\dot{Q}_{c}}{\dot{W}_{c o m p, e}+\dot{W}_{\text {pumps }, e}+\dot{W}_{\text {fans }, e}} .
$$

Ground-source heat pump was designed according to the European Standard EN 14511-2:2013 [11], [12]. Heat pump operation modes were selected B0/W35 and B0/W55. The European Standard BS EN 14825:2016:2016-03 was used for the domestic hot water production in the seasonal efficiency calculation [13], [14]. The advantage of standard EN14825 is that it includes all kinds of heat pumps (except exhaust air heat pumps). The model treats heat pumps both in heating and cooling operation. The fact that the heat pump is tested in part load should result in more sufficient results compared to degradation coefficient etc. The model is foreseeable and quite easy to follow, though it is not completely clear with its definitions of part loads respectively at the boiling point $-5{ }^{\circ} \mathrm{C}$ and reference state temperature $27^{\circ} \mathrm{C}$.

\section{Energy system model in TRNSYS}

TRNSYS (Transient System Simulation Program) is mainly used for simulation and analysis of buildings' thermal environment. The feature of this software is modular analytical methods. When simulating the air conditioning system, with the methods of set - calculation - feedback - set - calculation and through feedback, the user can correct system settings to make the calculation more precise. And all standard modules in TRNSYS software source code are open, so the user can modify and add module when it is necessary.

The heat pump is scheduled to run from 8 a.m. to 6 p.m. (day-time operation). This operation aims to determine the size of the storage tanks required, when the system operation time follows normal working hours in a building. The DST model is used in the vertical borehole heat exchanger (Type 557a) in TRNSYS 18. It is known as a fast and accurate simulation model for duct ground heat storage and has been extensively validated against other models and experimental measurements. Type 557a borehole geometry and composition is defined by the user (U-tube properties and grout properties). The TRNSYS model simulates the application of heat pump for simultaneous heating, cooling and air conditioning to meet daily residential usage in Odessa, Ukraine and is schematically shown in Fig. 2.

The air supplied to the room has temperature from 18 to $20^{\circ} \mathrm{C}$, while the hot water tank should have temperature not less than $55^{\circ} \mathrm{C}$. Auxiliary fluid heater (type 659 or type 6) is installed to provide temperature at $60{ }^{\circ} \mathrm{C}$. External proportional control (an input signal between 0 and 1) is in effect as long as a fluid set point temperature is not exceeded. If the set point is exceeded, the proportional control is internally modified to limit the fluid outlet temperature to the set point. Type 2 differential controllers will be used to monitor the tank temperatures which provide output signals used as part of conditions to operate the heat pump. Together with another controller that determines the pump operation based on time set in the controller which will be discussed in the next section.

The air supplied to the room has temperature from 18 to $20^{\circ} \mathrm{C}$, while the hot water tank should have temperature not less than $55^{\circ} \mathrm{C}$. Auxiliary fluid heater (type 659 or type 6) is installed to provide temperature at $60{ }^{\circ} \mathrm{C}$. External proportional control (an input signal between 0 and 1) is in effect as long as a fluid set point temperature is not exceeded. If the set point is exceeded, the proportional control is internally modified to limit the fluid outlet temperature to the set point. Type 2 differential controllers will be used to monitor the tank temperatures which provide output signals used as part of conditions to operate the heat pump. Together with another controller that determines the pump operation based on time set in the controller which will be discussed in the next section.

The control of the fancoils has been implemented with the TRNSYS type 2, which models a differential ON/OFF controller. With this type, the reference temperature is compared to an upper and a lower bound. When the temperature increases above the upper limit, the control signal switches to "1". Then, when the temperature decreases below the lower bound, the control signal switches to " 0 ". This control signal can be used directly for governing the fancoil switching in cooling mode, but it has to be inverted for the fancoil control in heating mode.

The subroutine models a VAV air handler for TRNSYS (Fig.3). The air handler contains a fan, heating coil, cooling coil and optional economizer and preheat coil. The model is intended to be connected to building models that can calculate sensible energy-rate-control loads (building Type 12c (single zone), Type 56 (multizone) etc.). Type 136 uses a manufacturer's catalog data approach to model an air to air heat pump section that might appear in an air handler. It does not include algorithms to mix return and fresh air, it does not include any auxiliary heating, and it does not include the ability to define a domestic/service water desuperheater. Because of the lack of these features, Type 136 can be used to model a DX Coil - Condenser component of an air handler. 


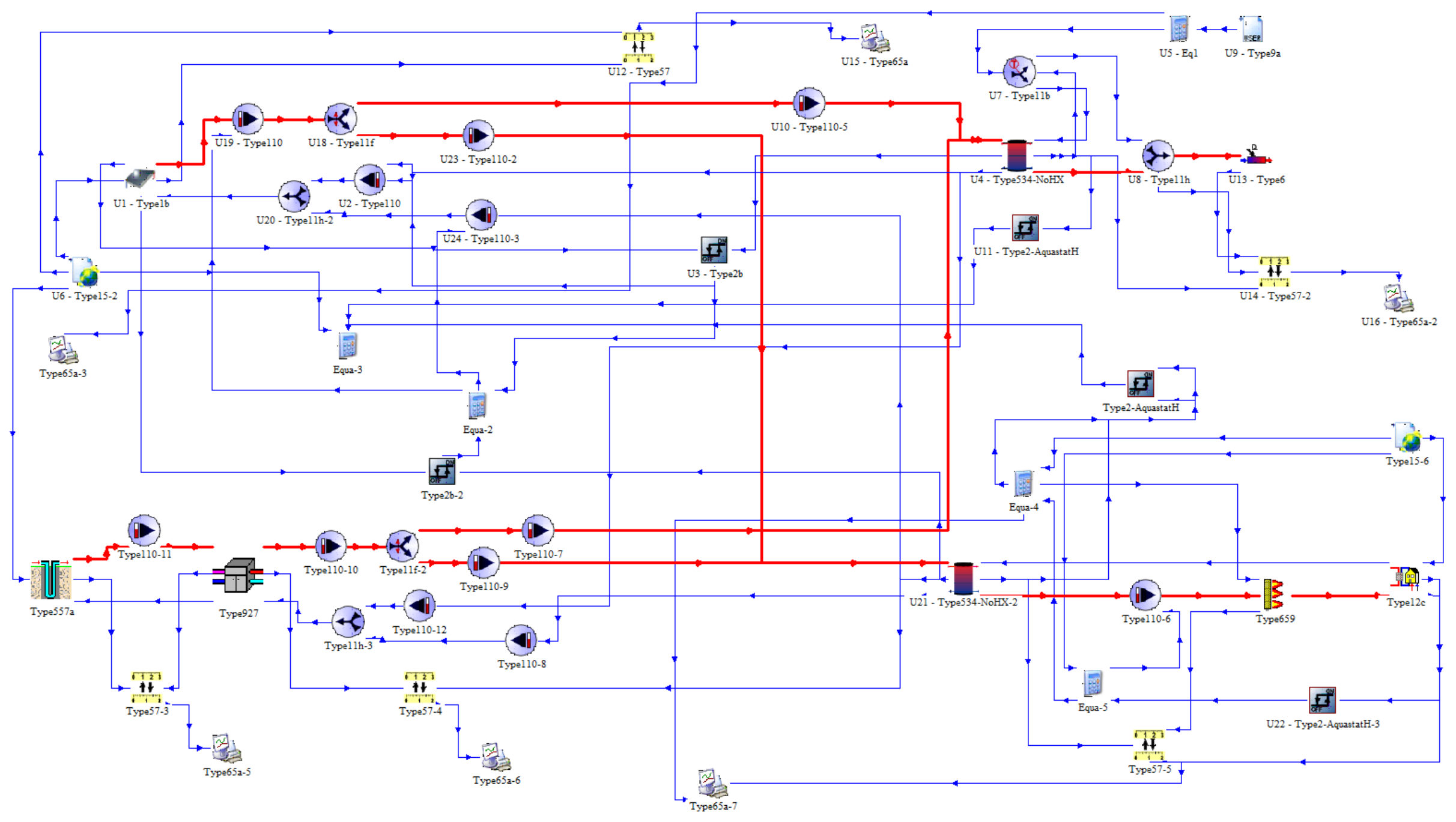

Fig.2. "Ground-source" heat pump model in TRNSYS. 


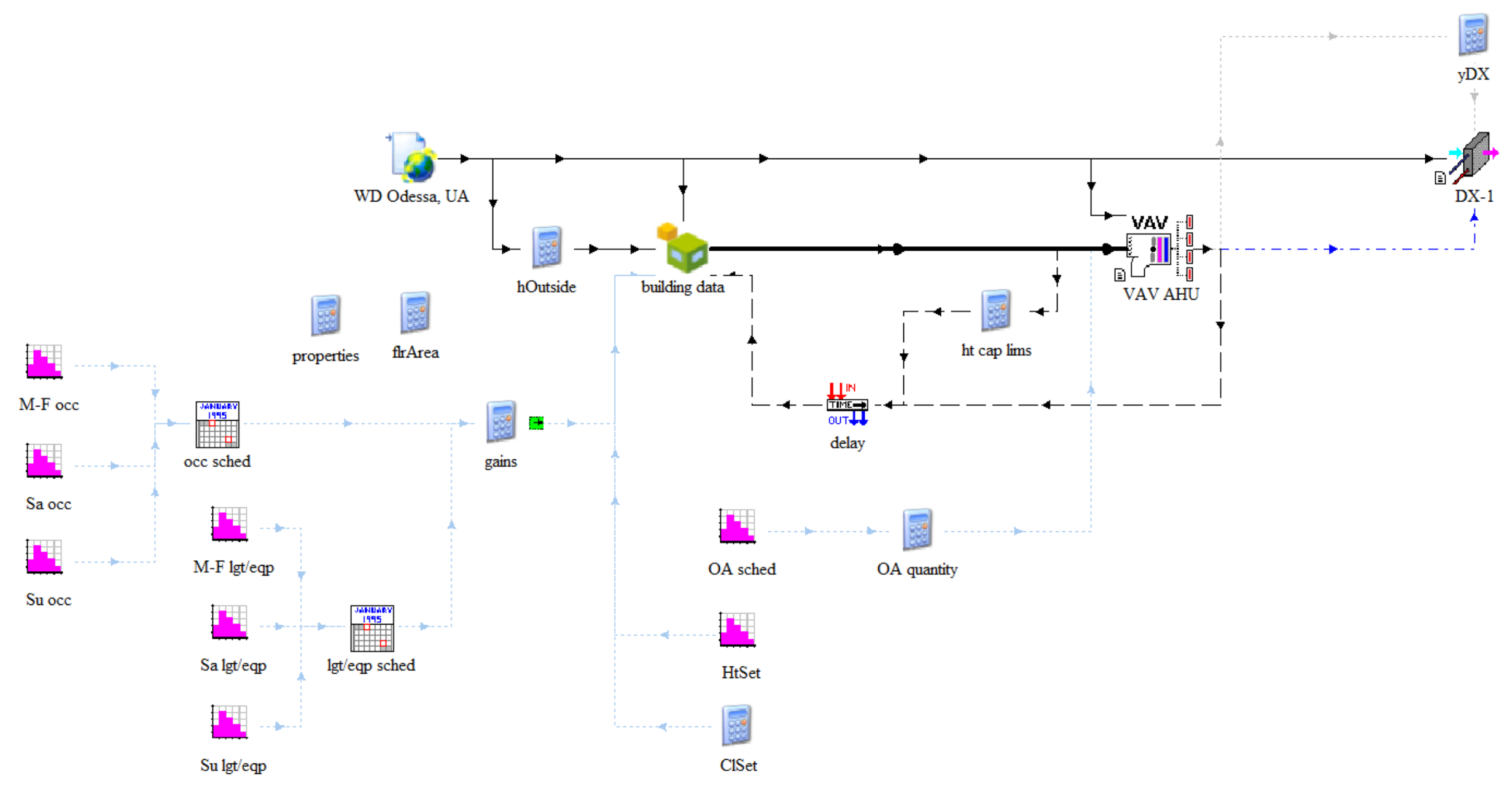

Fig.3. Air handling unit model in TRNSYS. 


\subsection{Solar collector modelling}

Oriented to the south and set at the angle of $30^{\circ}$ to $65^{\circ}$ to the horizon, solar collector is able to receive the yearly maximum amount of radiant energy. But even noticeable deviations from the above-mentioned conditions (the orientation of the south-west to south-east, the angle of inclination from 25 to 70 degrees), the solar system will run at peak efficiency. A smaller angle is optimal in the event that the surface of the collector cannot be oriented to the south. In this case, the solar collector, located at an angle of 30 degrees, even if the orientation is south-west, with an azimuth of $45^{\circ}$ will still provide up to $95 \%$ of the optimal solar power. And even when the orientation is east or west, you can still receive up to $85 \%$ of energy, with a roof inclination angle of $25^{\circ}$ to $40^{\circ}$. If the angle of the collector is greater, higher amount of incoming energy will be received through the year.

Since the insolation in the middle of the day is the most intense, the collector plane should be oriented as far as possible to the south. However, good results can be achieved in case of deviations from the south to $45^{\circ}$ south-east or south-east. Larger deviations can be compensated by a slight increase in the surface area of the reservoir. Solar collectors can be mounted and fixed on the surface of any buildings, structures or directly on the ground. Therefore, the minimum allowable angle at which they should be installed is $25^{\circ}$.

The collected useful energy is transferred to the hot liquid storage tank and the evaporator of the heat pump is supplied with input thermal energy. The solar radiation, $I_{T}$ is calculated using the following equation

$$
I_{T}=I_{b} R_{b}+I_{d} \frac{1+\cos \beta}{2}+\left(I_{b}+I_{d}\right) \rho \frac{1-\cos \beta}{2} .
$$

where $I_{b}$ is buffer solar irradiation; $I_{d}$ is direct solar irradiation; $R_{b}$ is the ratio of the instantaneous direct solar radiation on a tilted surface to the instantaneous direct solar radiation on a horizontal surface; $\beta$ is angle of the tilted surface.

The total irradiance on a tilted surface under clear sky conditions is calculated by the equations depending upon $R_{b}$ which is the ratio of the instantaneous direct solar radiation on a tilted surface to the instantaneous direct solar radiation on a horizontal surface:

$$
R_{b}=\frac{\cos (\varphi-\beta) \cos \delta \cdot \cos \omega+\sin (\varphi-\beta) \sin \delta}{\cos \varphi \cdot \cos \delta \cdot \cos \omega+\sin \varphi \cdot \sin \delta} .
$$

Table 1. The average annual amount of solar energy falling on a daily basis on a horizontal surface in different regions of Ukraine.

\begin{tabular}{|c|c|c|c|c|c|c|c|c|c|c|c|c|c|}
\hline $\begin{array}{c}\text { The average figure } \\
\text { for the last 22 } \\
\text { years (Acc. to } \\
\text { NASA) }\end{array}$ & Jan & Feb & Mar & Apr & May & Jun & Jul & Aug & Sep & Oct & Nov & Dec & $\begin{array}{c}\text { Year } \\
\text { avg. }\end{array}$ \\
\hline $\begin{array}{c}\text { Odessa, Latitude } \\
46.30 \text { N, } \\
\text { Longitude 30.46 E }\end{array}$ & 1.08 & 1.78 & 2.68 & 3.87 & 5.4 & 5.7 & 6.39 & 5.63 & 3.96 & 2.45 & 1.06 & 0.87 & 3.41 \\
\hline
\end{tabular}

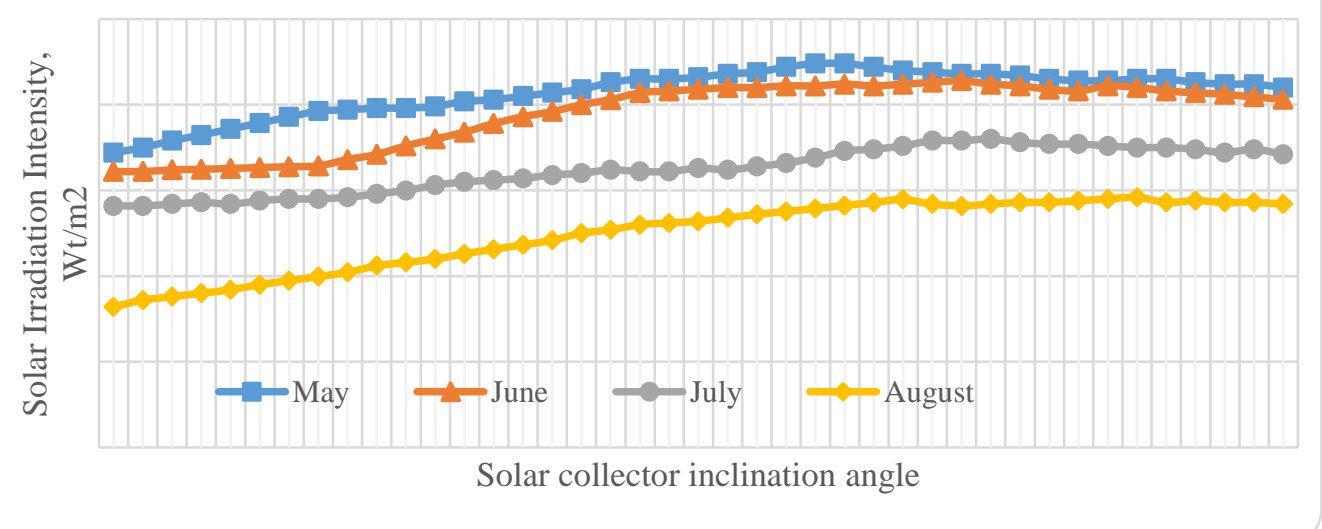

Fig. 4. The dependence of the solar irradiation intensity on the inclination angle of the solar collector. 
Solar collectors are modeled with the formulation as suggested by Duffie and Beckman:

$$
\dot{Q}_{u}=A_{c} I_{T} \eta_{c}
$$

where $\dot{Q}_{u}$ is the useful energy collected in system collectors; $A_{\mathrm{c}}$ is the collector area; $\eta_{c}$ is the collector efficiency.

The collector efficiency is calculated as follows:

$$
\eta_{c}=F_{R}\left[(\tau \alpha)-U_{L} \frac{T_{i n}-T_{0}}{I_{T}}\right]
$$

where $T_{\text {in }}$ is the collector inlet temperature; $T_{0}$ is the environment temperature. A water storage tank is placed after the solar collectors as shown in Fig.1. Perfect mixing within the tank is assumed. If the rate of heat addition and removal for a reasonable time period of $\Delta t$ are assumed to be constant, equations can be written for each time interval:

$$
T_{s t, n e w}=T_{s t, o l d}+\frac{\Delta t}{\left(m c_{v w}\right)_{s}}\left[\dot{Q}_{u}-\dot{Q}_{e}-(U A)_{s}\left(T_{s t}-T_{0}\right)\right]
$$

where $\dot{Q}_{e}$ is the extracted energy from the storage tank in the evaporator; $T_{s t}$ is the main storage temperature for the period; $m$ is the storage tank mass; $(U A)_{\mathrm{s}}$ is taken as $11.1 \mathrm{~W} / \mathrm{K}$.

Based on the modelling results, the feasibility of installing solar collectors in the heat pump system is obvious. The highest efficiency can be achieved in the warm season (from May till September), which will increase the efficiency of the heat pump in hot water production mode.

\subsection{Seasonal performance analysis of a heat pump}

Three systems were studied over a period of 1 year based on the estimated monthly ambient temperatures.

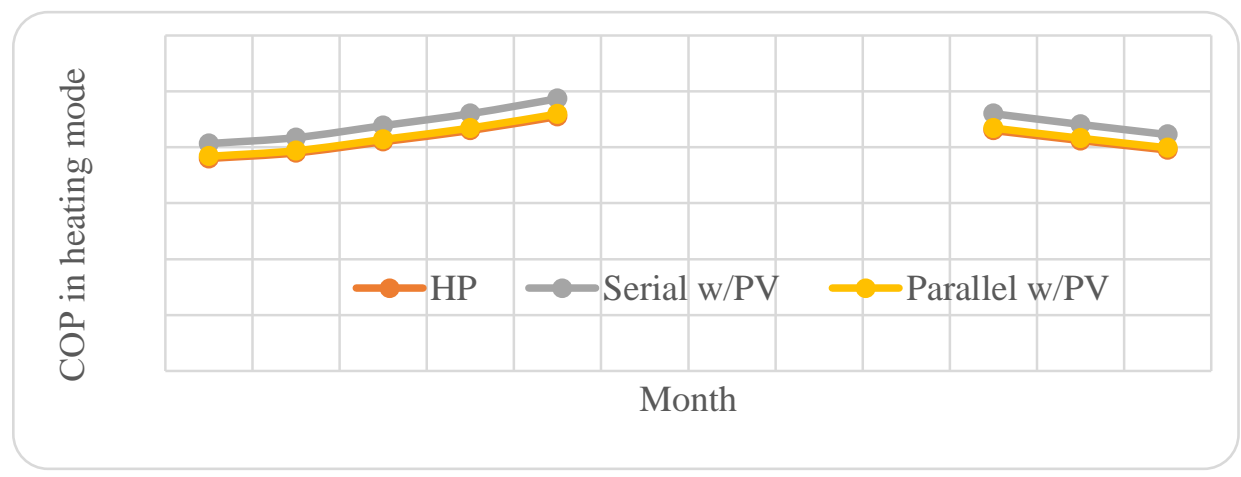

Fig.5. Heat pump COP in heating mode.

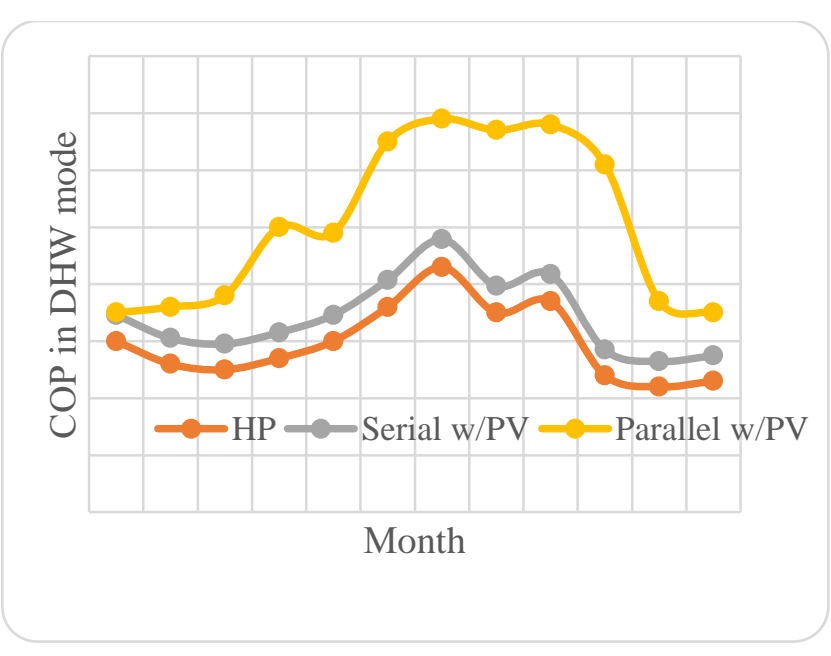

Fig.6. Heat pump COP in hot water mode.

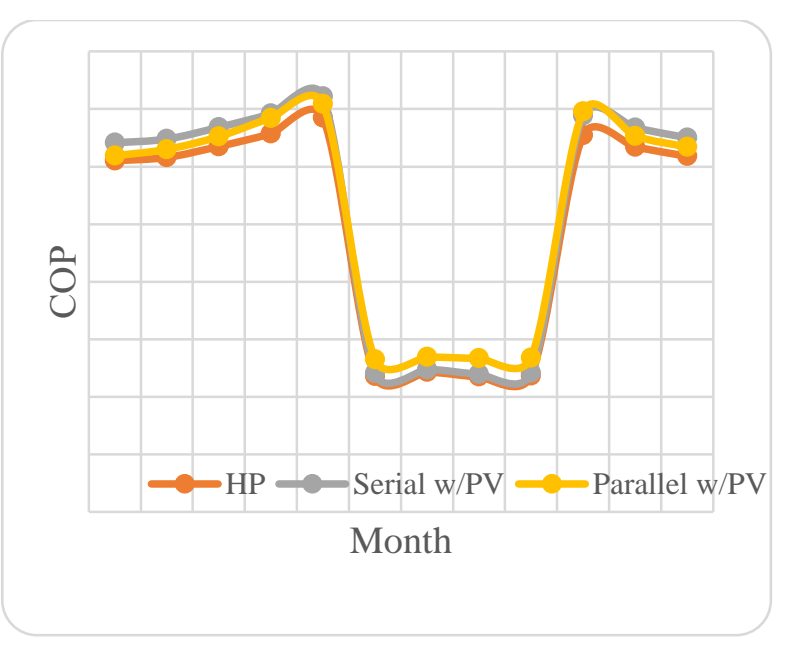

Fig.7. Heat pump COP. 
The systems were analyzed for COPs, the use of which can give an idea of heat pump performance.

It can be seen that for all systems the COP is significantly reduced in the summer due to the fact that all heat load is made up of DHW systems. The COP of the system in parallel mode has the lowest performance compared to other modes. This is due to the simultaneous operation of the solar system and the heat pump, which leads to higher water temperatures at the inlet to the heat pump One of the disadvantages of the systems is also the imperfection of the control system, since the heat pump is controlled separately from the solar system, it will work regardless of whether the capacity of the solar system is sufficient.

Seasonal Performance Ratio (SPF) applies only to heat pumps. This is an indicator of how well the heat pump is operating. The higher SPF value, the more energy efficient system is.

SPF is an indicator of the efficiency of the electric heat pump heating system during the year. This is the ratio of heat supplied to the total electricity supplied during the year.

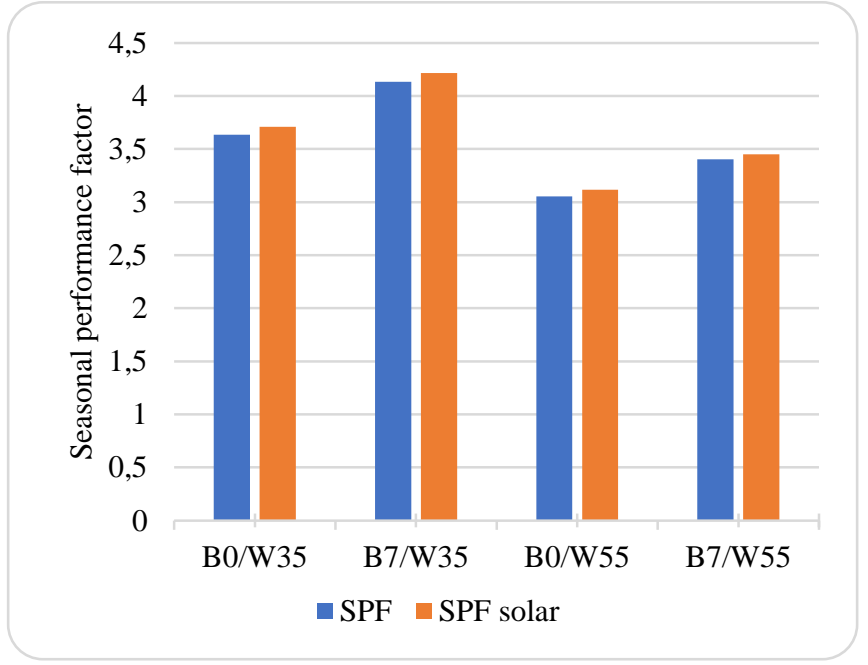

Fig.8. Seasonal performance factor for GSHP system.

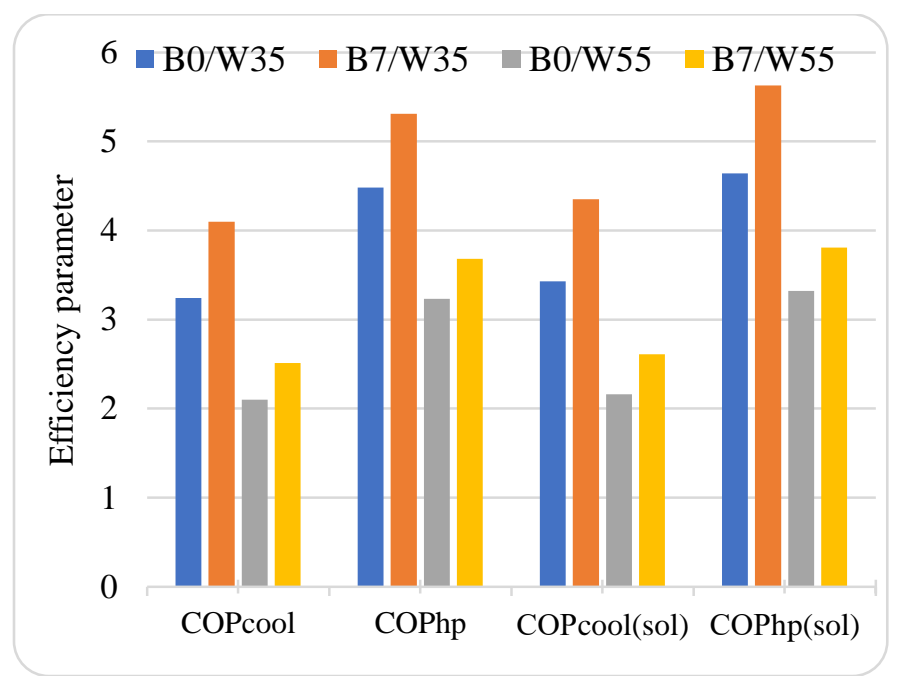

Fig.9. Energy efficiency ration and COP for energy system (integration of GSHP system with solar thermal system and without it).

Energy efficiency was calculated for different operation modes. Heat pump operation modes were selected B0/W35, B7/W35 and B0/W55, B7/W55. Calculations were made for heat pump system alone and with solar system working in series.

\section{Conclusion}

The need for decarburization or decrease in energy consumption in buildings and structures strongly encourages us to apply energy efficiency approaches, to design and deploy them by reducing energy consumption of buildings and to mainly use renewable sources energy instead, including renewable energy generated on-site, i.e. geothermal energy (source - soil). Increasing prices on energy resources and availability of the new technologies make it possible to implement alternative heating and cooling solutions. Solar thermal system allows increasing outlet temperature from ground heat exchanger and therefore increasing COP of the heat pump system by 4-6\% (dependent on the operating mode). TRNSYS 18 software was used for energy system simulation (integration of the ground source heat pump with solar system). The results had shown that the solar collector, located at an angle of 30 degrees, even if facing southwest, with azimuth of $45^{\circ}$, would still provide up to $95 \%$ of optimal solar energy. And even with east or west orientation, you can still obtain up to $85 \%$ energy, with roof angles of $25^{\circ}$ to $40^{\circ}$. If the collector angle is greater, more input energy will be obtained during the year.

The growth of the COP is caused by reduction of the electrical input to the heat pump because of higher temperature gain by solar collector. Solar thermal collector can reduce borehole depletion and can be used for ground heat exchanger regeneration during the heat pump stand by. Ukraine's southern region has great potential for solar energy use with solar irradiation between $1100-1300 \mathrm{kWh} / \mathrm{m}^{2}$. 


\title{
References
}

[1] International Energy Agency. 2019. Energy Efficiency Market Report 2019, OECD/IEA, 2019.

[2] The GABC Secretariat is located at UNEP's Economy Division. 2019. Global Alliance for Buildings and Construction. [on-line resources] accessed by URL: https://unfccc.int/news/global-alliance-for-buildings-and-construction

[3] BRE Group, BREEAM International New Construction 2016, Technical Standard, Building Research Establishment, Watford, [on-line resources] accessed by URL: https://hbreavis.com/wp-content/uploads/2017/06/BREEAM-International-New-Construction-2016.pdf.

[4] US Green Building Council. 2019. LEED V4 for Building Design and Construction, 2019. [on-line resources] accessed by URL: http://www.usgbc.org/resources/leed-v4-building-design-and-construction-current-version.

[5] Energy performance of buildings directive, Directive 2010/31/EU of the European Parliament and of the Council of 19 May 2010 on the Energy Performance of Buildings (Recast), [on-line resources] accessed by URL: https://www.eea.europa.eu/policy-documents/energyperformance-of-buildings-directive

[6] Oswaldo Lucon (Brazil), Diana Ürge-Vorsatz (Hungary). 2018. Buildings [on-line resources] accessed by URL: https://www.ipcc.ch/site/assets/uploads/2018/02/ipcc_wg3_ar5_chapter9.pdf

[7] Klijn-Chevalerias, M.; Javed, S. 2017. The Dutch approach for assessing and reducing environmental impacts of building materials. Building and Environment. [on-line resources] accessed by URL: https://www.ofcoursecme.nl/?mdocs-file=3806

[8] Antonio Ángel. 2016. Life Cycle Assessment in Building: A Case Study on the Energy and Emissions Impact Related to the Choice of Housing Typologies and Construction Process in Spain. Sustainability, \# 8, pp. 287-316.

[9] Afaf Azzouz. 2019. Life Cycle Assessment of Energy Conservation Measures during Early Stage Office Building Design: A Case Study in London, UK. [on-line resources] accessed by URL:

https://discovery.ucl.ac.uk/id/eprint/1552588/1/Mavrogianni_MANUSCRIPT_FINAL.pdf

[10] Randa Ghattas. 2013. Life Cycle Assessment for Residential Buildings: A Literature Review and Gap Analysis. Concrete Sustainability Hub Massachusetts Institute of Technology. [on-line resources] accessed by URL: https://cshub.mit.edu/sites/default/files/documents/LCAforResidentialBuildings.pdf

[11] Energy Performance of Buildings. Directive (EU) 2018/844 of the European Parliament and of the Council of 30 May 2018 amending Directive 2010/31/EU on the energy performance of buildings and Directive 2012/27/EU on energy efficiency (Text with EEA relevance) . [on-line resources] accessed by URL: https://eur-lex.europa.eu/legal-content/EN/TXT/?uri=uriserv\%3AOJ.L_.2018.156.01.0075.01.ENG

[12] European Standard BS EN 14511-2 (2013), Air conditioners, liquid chilling packages and heat pumps with electrically driven compressors for space heating and cooling - Part 2: Test conditions, published by CEN on 31 August 2013.

[13] Final Report IEA HPP Annex 28. Test procedure and seasonal performance calculation for residential heat pumps with combined space and domestic hot water heating. 2005. - 114 p.

[14] European Standard BS EN 14825 (2016), Air conditioners, liquid chilling packages and heat pumps, with electrically driven compressors, for space heating and cooling — Testing and rating at part load conditions and calculation of seasonal performance, published by CEN on March 2016.

\section{Енергетичний аудит комплексної енергетичної системи змодельованої за допомогою програмного забезпечення TRNSYS}

\author{
Володимир Бежан $^{a}$, Володимир Житаренко ${ }^{a}$, Ольга Яковлева ${ }^{b}$, \\ Олексій Остапенко ${ }^{b}$, Михайло Хмельнюк ${ }^{b}$ \\ ${ }^{a}$ Приазовський державний технічний університет, вул. Університетська, 7, Маріуполь, 87555, Украӥна \\ ${ }^{b}$ Одеська наиіональна академія харчових технологій, вул. Дворянська, 1/3, Одеса, 68058, Украӥна
}

\section{Анотація}

Енергоаудит допомагає виявити енергетичний потенціал, розробити програму енергозбереження з метою підвищення енергоефективності під час процесу прийняття рішення про розробку на ранніх стадіях для нових розроблених систем, що може знизити витрати для власника проекту та для замовника. У даній роботі представлено використання складної енергетичної системи (теплового насоса з використанням сонячної енергії) для нагрівання та охолодження. Моделювання виконуються для складної енергетичної системи, розташованої на північній широті, за допомогою програмного забезпечення TRNSYS 18. Наведено результати конфігурацій системи. Результати показують, що сонячний колектор, встановлений під кутом 30 градусів, виходячи на південний захід, з азимутом $45^{\circ}$, пропонує до $95 \%$ оптимальної сонячної енергії. Для східної або західної орієнтації можна отримати до $85 \%$ енергії з кутами покрівлі від $25^{\circ}$ до $40^{\circ}$. 3 використанням сонячного теплового колектора замовник може зменшити виснаження свердловини, що може бути чудовими можливостями для будівельних секторів.

Ключові слова: енергетичний аудит; TRNSYS 18; геотермальний тепловий насос; кондиціонування; енергоефективність. 